\title{
Arya Penangsang: Santri Kesayangan Sunan Kudus sebagai Pembangun Memori Kolektif dalam Revitalisasi Kota Cepu
}

\author{
Sukarjo Waluyo ${ }^{*}$ \\ 1 Fakultas Ilmu Budaya, Universitas Diponegoro, Indonesia; sukarjowaluyo@gmail.com \\ * Correspondence: sukarjowaluyo@gmail.com
}

Received: 2021-02-03; Accepted: 2021-06-27; Published: 2021-08-23

\begin{abstract}
The issue of locality emerged in line with the 1998 reform movement, one of which demanded decentralization of development, including culture. The local identity of the Cepu community is important in this study. Talking about Cepu City cannot be separated from the Islamic Sultanate of Demak, Sunan Kudus, and Arya Penangsang. Arya Penangsang is the grandson of Raden Patah (founder of the Islamic Sultanate of Demak), Sunan Kudus's favorite religious and intelligent student. He is also the Duke of Jipang (Cepu of the past) who is known to be wise, brave, and a staunch Muslim. However, Cepu is an old city that historically has always been defeated, especially after the collapse of the Islamic Sultanate of Demak which was replaced by Javanese rulers in Pajang and Mataram. In the coastal areas he was known as the prince of the last heir to the Islamic Sultanate of Demak who was killed dramatically. The representation of Cepu's local identity comes through the figure of Arya Penangsang and efforts to revitalize the past glory of Jipang Kadipaten as a means of articulation. Interestingly, Arya Penangsang is a figure whom the rulers and most of the Javanese people regard as an evil, cruel, and power-hungry rebel. Thus, efforts to represent the local identity of the Cepu community clash with the dominant discourse of Javanese society in general. Using the ethnographic method, this article aims to express the love of the Cepu people towards Arya Penangsang and the Kadipaten Jipang. The results of this study will explain how Arya Penangsang and the past glory of the Kadipaten Jipang have been awakened in the collective memory of the Cepu people. Arya Penangsang and the Kadipaten Jipang are currently constructed as local heroes in discourses on the revitalization of Cepu City. The results of this study contribute to become a model for the revitalization of other cities that have the same issue.
\end{abstract}

Keywords: Arya Penangsang; city revitalization; collective memory; local identity; representation; resistance.

Abstrak: Isu lokalitas muncul seiring dengan gerakan reformasi 1998, yang salah satu tuntutannya adalah desentralisasi pembangunan, termasuk kebudayaan. Identitas lokal masyarakat Cepu adalah hal penting dalam penelitian ini. Berbicara tentang Kota Cepu tidak lepas dari Kesultanan Islam Demak, Sunan Kudus, dan Arya Penangsang. Arya Penangsang adalah cucu Raden Patah (pendiri Kesultanan Islam Demak), santri kesayangan Sunan Kudus yang religius dan pandai. Ia juga Adipati Jipang (Cepu masa lalu) yang dikenal bijaksana, pemberani, dan pemeluk Islam yang teguh. Namun, Cepu merupakan kota tua yang secara historis selalu terkalahkan, terutama pasca runtuhnya Kesultanan Islam Demak yang digantikan oleh penguasa Jawa di Pajang dan Mataram. Di daerah pesisir ia dikenal sebagai pengeran pewaris terakhir Kesultanan Islam Demak yang terbunuh dengan dramatis. Representasi identitas lokal Cepu hadir melalui sosok Arya Penangsang dan upaya merevitalisasi kejayaan masa lalu Jipang Kadipaten sebagai alat artikulasi. Menariknya, Arya Penangsang adalah sosok yang oleh para penguasa dan sebagian besar masyarakat Jawa dianggap sebagai pemberontak yang jahat, bengis, dan haus kekuasaan. Dengan demikian, upaya merepresentasikan identitas lokal masyarakat Cepu berbenturan dengan wacana dominan masyarakat Jawa pada umumnya. Dengan metode etnografi, artikel ini bertujuan untuk mengungkapkan kecintaan masyarakat Cepu terhadap Arya Penangsang dan Kadipaten Jipang. 
Hasil penelitian ini akan menjelaskan bagaimana Arya Penangsang dan kejayaan Kadipaten Jipang masa lalu telah terbangun dalam memori kolektif masyarakat Cepu. Arya Penangsang dan Kadipaten Jipang saat ini dikonstruksi sebagai pahlawan lokal dalam wacana revitalisasi Kota Cepu. Hasil penelitian ini memberikan kontribusi untuk menjadi model bagi revitalisasi kota-kota lain yang memiliki yang memiliki isu sama.

Kata Kunci: Arya Penangsang; identitas lokal; memori kolektif; representasi; resistensi; revitalisasi kota.

\section{Pendahuluan}

Isu lokal di Indonesia adalah permasalahan yang banyak mendapat perhatian pascareformasi 1998. Pemerintahan era Orde Baru yang sentralistik dan terpusat di Jakarta berubah menjadi desentralistis dengan konsep otonomi daerah. Berdasarkan Undang-Undang Nomor 12 Tahun 2008 tentang Pemerintahan Daerah, daerah mempunyai kewajiban melestarikan nilai-nilai sosial budaya. Bagi pemerintah daerah, hal ini adalah kesempatan untuk melakukan improvisasi dengan melibatkan akademisi, budayawan, seniman, dan tokoh masyarakat Beberapa kota di Jawa Tengah mulai mengidentifikasi kekayaan sejarah, seni, dan budaya lokal untuk diangkat menjadi ikon dan identitasnya. Ikon dan identitas adalah proses organisasi sosial yang terus berlangsung dan menjadi isu penting pada masa kini (Leve, 2011, hal. 513-535). Kota Cepu (bagian dari Kabupaten Blora) memiliki pahlawan lokal yang kontroversial dalam sejarah Pulau Jawa, yaitu Arya Penangsang. Pemilihan tokoh Arya Penangsang adalah sebuah representasi yang merupakan hal penting yang memproduksi kebudayaan (Waluyo \& Noor Ary Setyadi, 2020). Kebudayaan merupakan konsep yang sangat luas, kebudayaan menyangkut 'pengalaman berbagi'. Seseorang dikatakan berasal dari kebudayaan yang sama jika orang-orang yang ada di suatu tempat tersebut membagi pengalaman yang sama, membagi kode-kode kebudayaan yang sama, berbicara dalam 'bahasa' yang sama, dan saling berbagi konsep-konsep yang sama (Suart Hall, David Held, 1992, hal. 274-316).

Arya Penangsang adalah penguasa Kadipaten Jipang pada pertengahan abad ke-16. Jipang merupakan sebuah wilayah vazal Kesultanan Demak. Babad Tanah Djawi mengisahkan Arya Penangsang membunuh Pangeran Prawata setelah Sultan Trenggana (pamannya dan ayah Pangeran Prawata) wafat. Pembunuhan tersebut, atas restu ulama terkemuka di Jawa yaitu Sunan Kudus, dilakukan karena Pangeran Prawata dulu pernah membunuh ayahnya (Pangeran Sekar). Sultan Trenggana naik tahta menjadi Sultan Demak III yang seharusnya menjadi hak Pangeran Sekar. Pembunuhan oleh Arya Penangsang tersebut dilakukan untuk meminta hak "tahta Demak" yang seharusnya menjadi hak ayah Arya Penangsang (Olthof, 1987, hal. 46-58).

Dalam cerita tutur Jawa, setelah terbunuhnya Pengeran Prawata, suksesi Kesultanan Demak mengalami kebuntuan. Hal ini memunculkan tiga ksatria yang kuat, yaitu Ratu Kalinyamat (adik Pangeran Prawata dan istri Pangeran Hadlirin, seorang Adipati Jepara), Hadiwijaya (Adipati Pajang), dan Arya Penangsang (Adipati Jipang). Sunan Kudus menyarankan Arya Penangsang, sebagai murid kesayangan, membunuh Pangeran Hadliri dan Hadiwijaya agar bisa menjadi Sultan Demak. Pangeran Hadlirin berhasil dibunuh tetapi pembunuhan atas Hadiwijaya mengalami kegagalan. Ratu Kalinyamat akhirnya menyarankan Hadiwijaya membunuh Arya Penangsang. Hal ini untuk membalas kematian Pengeran Prawata dan Pangeran Hadlirin. Ratu Kalinyamat akan menyerahkan wilayah Jepara dan Prawata serta seluruh harta kekayaannya jika Hadiwijaya berhasil (Waluyo, 2020, hal. 3). Hadiwijaya akhirnya menyerang Kadipaten Jipang dan berhasil membunuh Arya Penangsang. Arya Penangsang selanjutnya dicitrakan buruk, sedangkan Hadiwijaya naik tahta menjadi Sultan Pajang. Wacana buruk sengaja dibangun oleh Kesultanan Pajang yang mengklaim sebagai pewaris Kesultanan Demak. Sementara itu, Kesultanan Mataram, Keraton Surakarta, dan Keraton Yogyakarta untuk kepentingan hegemoni dan kekuasaan juga melanjutkannya. Babad Tanah Djawi menggambarkan Arya Penangsang sebagai pemberontak yang jahat, kasar, dan haus kekuasaan 
Di sisi lain, Arya Penangsang adalah pahlawan bagi masyarakat Cepu. Kisah Arya Penangsang melibatkan simbol-simbol, mitos, tempat, dan kisah heroisme Arya Penangsang yang bisa ditemukan sampai sekarang. Heroisme Arya Penangsang adalah sarana mengungkapkan perkembangan gagasan, keinginan, permintaan, keraguan, dan harapan (Waluyo, 2019)). Penulisan kisah Arya Penangsang dalam Babad Tanah Djawi yang digambarkan sebagai tokoh yang hitam seutuhnya berseberangan dengan sikap masyarakat Cepu. Dalam buku The Hidden History (2013), Aden mengungkapkan bahwa sejarah memiliki sisi gelap, sisi yang tidak boleh disentuh. Selanjutnya hanya dengan memutus satu mata rantai perjalanan sejarah kemudian bisa dibelokkan (Aden, 2013).

Dalam pandangan Hobswamb (1983), kisah Arya Penangsang bisa dianggap 'invented tradition' yang diartikan sebagai sebuah kesatuan tindakan yang didasari pada aturan dan ritual atau simbol keaslian. Kegiatan tersebut memiliki fungsi dan nilai dari sebuah kebiasaan dimana secara otomatis dipengaruhi oleh keberlangsungan di masa lampau.

[which] is taken to mean a set of practices, normally governed by overtly or tacitly accepted rules and of a ritual or symbolic nature, which seek to inculcate certain values and norms of behavior by repetition, which automatically implies continuity with the past.... [it] is essentially a process of formalization and ritualization, characterized by reference to the past, if only by imposing repetition (Hobswamb \& Ranger, 1983).

Kepahlawanan Arya Penangsang dan hal-hal yang melingkupinya dalam perjalanannya merupakan representasi lokal Cepu. Kaitan antara signifikansi identitas sebagai sumber daya dan sarana yang memobilisasi "perbedaan" oleh Hall dirumuskan melalui pertanyaan "Siapa saja yang membutuhkan identitas? Siapa yang diuntungkan dan siapa yang dirugikan?" (Suart Hall, David Held, 1992). Pengakuan atas kepahlawanan Arya Penangsang bagi masyarakat Cepu berarti pemberian otoritas. Semakin kuat identitas dan eksistensi suatu komunitas maka akan semakin meningkat otoritas komunitas tersebut. Otoritas ini tidak hanya eksistensi Arya Penangsang sebagai pahlawan lokal, tetapi berpengaruh luas dalam aspek-aspek kehidupan lainnya, seperti ekonomi, sosial, sejarah, dan politik. Penelitian serupa yang mengungkapkan kepahlawanan tokoh yang bagi arus dominan dianggap tokoh kontroversial pernah dilakukan beberapa peneliti seperti Orrin E. Klapp yang mengungkapkan ada tipe kepahlawanan martir (the martyr hero) yaitu kematian seorang tokoh yang bagi kelompok masyarakat tertentu dianggap sebagai pahlawan yang sangat dihormati, sebagaimana Achilles di Yunani dan Robin Hood di Inggris (Klapp, 1949, hal. 17-25). Julian M. Luxford mengungkapkan tentang Robin Hood yang dikenal sebagai legenda atau cerita rakyat yang diceritakan dalam bentuk lirik lagu balada dan merupakan hiburan populer pada abad pertengahan. Robin Hood digambarkan sebagai pelanggar hukum, pembuat onar, dan pencuri kayu. Namun, ia dianggap sebagai pahlawan oleh masyarakat seiring dengan ketidaksukaan masyarakat terhadap petinggi Kerajaan Inggris yang otoriter dan bertindak semena-mena terhadap masyarakat (Luxford, 20093, hal. 70-76)

Persepsi dan pergeseran sosok kepahlawanan diungkapkan oleh Nancy K. Nanney atas tokoh Hang Jebat di Malaysia. Pada tahun 190-an, Hang Jebat justru menjadi figur yang disukai masyarakat. Terjadilah evolusi kepahlawanan (hero evolution) sebagai akibat reinterpretasi melalui naskah dan sandiwara bahwa Hang Jebat bukanlah pemberontak, tetapi sosok yang menuntuk keadilan (Nanney, 1988, hal. 3-15). Sementara itu, Larson mengungkapkan bahwa Che Guevara adalah sosk misterius, khususnya bagi masyarakat Amarika Latin. Sosok yang dipuja oleh masyarakat, tetapi dianggap musuh oleh penguasa danpemimpin negara (Larson \& Lizardo, 2007, hal. 425-451). Che Guevara adalah bentuk dekonstruksi dan ikonisasi pahlawan pembela rakyat yang tertindas (Weiser, 2013, hal. 700-711). Penelitian ini berkaitan dengan mengangkat kembali kepahlawanan tokoh Arya Penangsang dan upaya revitalisasi kejayaan masa lalu Kadipaten Jipang di Cepu (Blora). Semua hal tersebut tampak dalam pembangunan infrastruktur (jalan, situs-situs, monumen, dan taman kota), menghidupkan kembali adat dan budaya Jipang (pendirian Yayasan Keraton Jipang dan penetapan Raja Jipang), dan gelar budaya Jipang yang semakin intens diadakan. Hal tersebut hadir sebagai memori kolektif masyarakat Cepu. Memori kolektif dalam perspektif Halbswach adalah sebuah rekonstruksi tentang masa lalu dalam nuansa kekinian (Green, 2004, hal. 
35-44). Konstruksi pemikiran versi Halbswach ini menegasikan tentang pentingnya peran individual dalam membentuk suatu memori kolektif. Bagi Kansteiner, memori kolektif bukanlah sejarah, walaupun terkadang mengambil dari material yang sama. Ia merupakan fenomena kolektif, tetapi hanya tampak dalam tindakan dan pernyataan dari individu (Wulf Kansteiner, 2002, hal. 179-197). Memori kolektif merupakan kumulatif dari narasi-narasi personal, kemudian narasi personal yang mempunyai kesamaan itulah yang ditransmisikan menjadi memori kolektif.

Penelitian ini berkaitan dengan memori kolektif masyarakat Cepu atas tokoh Arya Penangsang dalam menuntut keadilan yang disertai simbol-simbol, mitos dan kisah heroisme. Penelitian dilakukan di Cepu dan sekitarnya antara bulan Januari - Juni 2018 dengan metode etnografi yang relevan dengan realitas sosial budaya masyarakat setempat (Spradley, 2007). Masalah dalam artikel ini adalah siapa sebenarnya tokoh Arya Penangsang, bagaimanakah pandangam masyarakat Cepu atas tokoh Arya Penangsang, dan bagaimanakah upaya masyarakat Cepu untuk mengonstruksi kembali tokoh Arya Penangsang dan kejayaan Kadipaten Jipang pada masa lalu.

\section{Arya Penangsang: Pembangun Memori Kolektif dalam Revitalisasi Kota Cepu}

Cepu adalah kota tua di Kabupaten Blora, Provinsi Jawa Tengah. Cepu terletak di ujung timur Kabupaten Blora, Provinsi Jawa Tengah dan berbatasan dengan Kecamatan Padangan, Kabupaten Bojonegoro bagian barat, Provinsi Jawa Timur. Cepu adalah magnet dari beberapa wilayah di sekitar Blora dan Bojonegoro saat berbicara sejarah, budaya, dan identitas. Dengan luas wilayah $48,97 \mathrm{~km}^{2}$, jumlah penduduk 77.880 jiwa, dan kepadatan 1.590 jiwa/km², Cepu merupakan kota terbesar kedua di Kabupaten Blora, setelah Kota Blora.

Cepu adalah pusat pendidikan, industri, jasa, dan perekonomian bagi wilayah di Kabupaten Blora bagian timur dan Kabupaten Bojonegoro bagian barat. Pembangunan infrastruktur cukup baik untuk sebuah kota kecil di Indonesia, termasuk ruang publik dan taman-taman kota. Cepu sudah dikenal sejak zaman Panembahan Senapati (Raja Mataram I) berkuasa di tanah Jawa. Penamaan Cepu konon berkaitan peperangan antara Jipang dengan Pajang di pinggir Bengawan Solo. Alkisah, ada seorang prajurit Jipang (ada yang mengatakan bukan prajurit biasa, melainkan Arya Penangsang) yang tertancap tombak di pahanya. Dalam bahasa Jawa, tancap adalah nancep, paha adalah pupu. Dua kata tersebut digabung menjadi Серu (J.F.X. Hoery (72), budayawan Cepu dalam wawancara di rumahnya di Jalan Diponegoro, Padangan, Bojonegoro, tanggal 8 Januari 2018).

Cepu adalah kota penting pada masa kolonialisme Belanda karena kaya kandungan minyak bumi dan kayu jati dengan kualitas terbaik. Beberapa bangunan peninggalan masa kolonialisme Belanda masih bisa dijumpai hingga hari ini, seperti gedung Loji Klunthung, Gedung Sasono Suko (SOS), dan Kuburan Londo (Makam Belanda). Untuk mendukung transportasi masa itu, Pemerintah kolonial Belanda membangun jalur kereta api yang menghubungkan Jawa Tengah - Jawa Timur via Cepu. Sementara itu, landasan pesawat terbang zaman kolonialisme Belanda bisa disaksikan di Desa Ngloram.

Menurut penuturan J.F.X. Hoery, pada masa lalu Cepu menjadi tempat pelarian sisa-sisa para pemberontak PKI Madiun 1948 yang akhirnya bisa ditumpas militer Divisi Ronggolawe yang dipimpin GPH Djatikoesoemo. Nama Ronggolawe pada akhirnya diangkat menjadi salah satu ikon Kota Cepu pada masa pemerintahan Sukarno (Orde Lama) dan Suharto (Orde Baru). Nama Ronggolawe diabadikan menjadi nama Lapangan Ronggolawe, Sekolah Tinggi Teknologi Ronggolawe, dan Monumen Ronggolawe. Monumen Ronggolawe berupa patung kuda jantan berwarna hitam yang sedang mengangkat kedua kaki depannya sebagai lambang militer Divisi Ronggolawe. Namun, masyarakat Cepu kemudian mempersepsikan Monumen Ronggolawe tersebut sebagai patung Kuda Gagak Rimang, kuda perang kesayangan milik Arya Penangsang.

\section{Arya Penangsang: Anak Raden Kikin dan Cucu Raden Patah}

Kota Cepu dan sekitarnya, yaitu wilayah di sekitar Sungai Bengawan Solo yang membelah Pegunungan Kendeng, memiliki ikatan kuat dengan sejarah dan budaya Arya Penangsang dan Kadipaten Jipang. Sejarah, budaya, dan identitas Cepu adalah spirit dan inspirasi, khususnya bagi 
Kabupaten Blora bagian timur dan Kabupaten Bojonegoro bagian barat. Meskipun masyarakat Jawa di Surakarta dan Yogjakarta mempersepsikan Arya Penangsang sebagai pemberontak, tetapi masyarakat Cepu justru berpandangan sebaliknya. Bagi mereka Arya Penangsang adalah pemimpin yang tegas, berani membela kebenaran, dan berani menuntut hak. Oleh karena itu, saat pembelajaran dengan materi sejarah Kesultanan Demak dan Kadipaten Jipang, guru sejarah di Cepu umumnya mengeksplorasi pandangan masyarakat Cepu sesuai dengan yang para siswa pahami (Ogy Yuda Herlangga (28), guru sejarah di SMA Negeri 1 Cepu, tanggal 5 Januari 2018).

Herlangga yang tergabung dalam komunitas Forum Peduli Sejarah Budaya Blora (FPSBB) mengatakan bahwa isu lokalitas, sejarah, dan budaya merupakan hal yang banyak didiskusikan masyarakat dari waktu ke waktu di Kota Cepu. Profesinya sebagai guru Sejarah dan keterlibatannya dalam komunitas peduli budaya membuatnya memiliki tanggung jawab atas sejarah dan budaya. Ia turut berpartisipasi memberikan pencerahan pada masyarakat bahwa Cepu memiliki modal lokalitas dalam membangun kota.

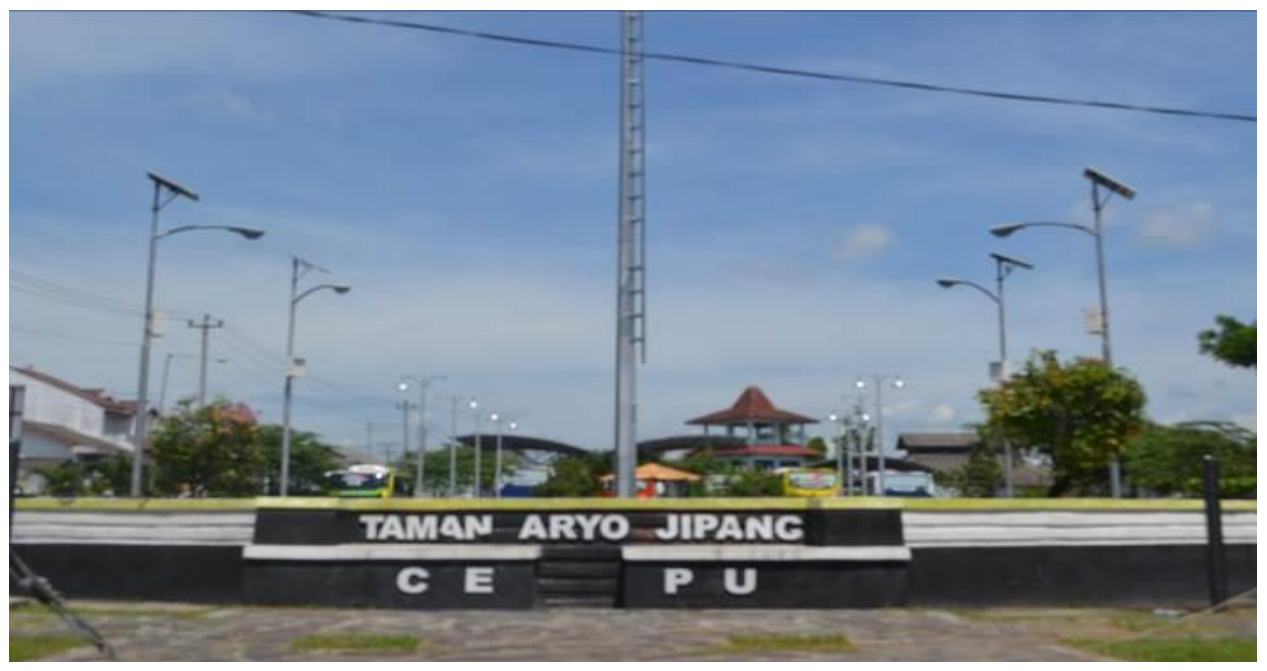

Gambar 1 Taman Aryo Jipang di pintu masuk Kota Cepu

Sumber: Sukarjo Waluyo

Membicarakan sejarah dan budaya tidak mengajak kembali ke masa lalu, tetapi modal membangun Cepu ke depan dalam perspektif politik dan ekonomi, misalnya dengan pemilihan Cepu sebagai destinasi wisata sejarah dan budaya. Cepu adalah daerah yang memiliki sejarah lengkap sejak zaman prasejarah, masa kerajaan Hindu-Budha, masa kerajaan Islam dan penyebaran agama Islam di Jawa, masa kolonialisme Belanda, hingga Indonesia merdeka. Jika hal ini menjadi perhatian pemerintah daerah, Cepu akan menjadi kota yang memiliki masa depan cerah (Ahmad Zamroni (35), budayawan lokal Cepu di rumahnya di Desa Cendono, Padangan, Bojonegoro, tanggal 6 Januari 2018). Gambar 1 Taman Aryo Jipang di pintu masuk Kota Cepu menunjukkan bahwa sosok Arya Penangsang menjadi ikon kota yang sangat dihormati oleh masyarakat Cepu.

Zamroni melihat ada upaya dari pihak para penguasa Jawa untuk mendiskreditkan Cepu sejak kekalahan Kadipaten Jipang dan terbunuhnya Arya Penangsang pada masa lalu (sekitar tahun 1549). Arya Penangsang yang jasadnya dimakamkan jauh dari wilayah Jipang, yaitu di Kadilangu (sebelah timur Kota Demak yang berjarak sekitar $138 \mathrm{~km}$ dari Kota Cepu), adalah indikasi penguasa tidak ingin melihat Cepu memiliki kekuatan politik, budaya, dan ekonomi. Dalam kasus PKI Madiun 1948 dan G 30 S/PKI 1965, Cepu dipersepsikan sebagai daerah pemberontak, padahal kondisi Cepu saat itu sama saja dengan daerah-daerah lain di sekitarnya. Zamroni mengungkapkan kecurigaannya atas upaya pihak penguasa atas Kota Cepu dengan semboyan bernada sindiran, "Cepu adalah daerah kaya raya yang harus selalu dikalahkan." Ini senada dengan keyakinan dalam masyarakat Cepu yang percaya bahwa mereka akan sulit berkembang jika tidak merantau atau keluar dari Cepu. "Keluarlah dari Cepu jika ingin jadi orang besar!" kata Zamroni menyebut adagium masyarakat Cepu. Ia menyebut nama-nama seperti Mas Marco Kartodikromo, Tirto Adhi Soerjo, Kartosuwiryo, Mukti Ali, 
LB Murdani, dan Pramudya Ananta Toer sebagai representasi orang Cepu dan Blora sebagai tokoh besar dalam panggung sejarah Indonesia.

Upaya Yayasan Keraton Jipang di Kota Cepu untuk menghidupkan kejayaan masa lalu Kadipaten Jipang mendapatkan banyak respon positif. Pada tahun 2014 Yayasan Keraton Jipang secara resmi berdiri. Dalam catatan Yayasan Keraton Jipang, Jipang adalah sebuah kerajaan kecil pada masa Kerajaan Majapahit (meliputi lima wilayah kabupaten sekarang: Blora, Rembang, Pati, Kudus, dan Bojonegoro) yang otonom dan dibebaskan dari kewajiban membayar pajak pada Majapahit. Kehancuran Majapahit dan berdirinya Kesultanan Demak membuat Jipang memilih bergabung pada Demak karena pandangan politik, khususnya berkaitan Islamisasi di Jawa (Kushariyadi (52), Ketua Yayasan Keraton Jipang dalam wawancara di rumahnya di Desa Demaan, Padangan, Bojonegoro, tanggal 7 Januari 2018).

Saat Demak berkonflik dengan bekas Majapahit, Jipang adalah pendukung utama Demak. Jipang secara geografis berbatasan langsung dengan wilayah Majapahit dan memiliki militer yang kuat (Laskar Soreng). Ada keyakinan, jika Jipang sebagai wilayah perbatasan kalah menghadapi bekas kekuatan Majapahit maka proses Islamisasi tanah Jawa dan politik Demak akan kalah. Sebaliknya, jika Jipang menang maka Demak akan menjadi pewaris kebesaran Majapahit. Sumbangan Jipang juga dibuktikan dengan kepemimpinan tokoh Jipang sebagai panglima perang Demak dalam penyerangan ke jantung pertahanan Majapahit, yaitu Sunan Ngudung. Sunan Ngudung adalah ayah Sunan Kudus berasal dari daerah Ngudung (sebuah daerah di dekat Jipang) (Graaf, 1985; Graaf \& Pigeaud, 1985).

Herlangga, Zamroni, dan Kushariyadi mengatakan bahwa bagi masyarakat Cepu, pembunuhan yang dilakukan Arya Penangsang atas Pangeran Prawata adalah murni balas dendam dan meminta hak tahta Kesultanan Demak di masa lalu yang seharusnya menjadi hak ayahnya. Setelah membunuh Pangeran Prawata (Sultan Demak IV), atas restu Sunan Kudus, Arya Penangsang menobatkan diri sebagai Sultan Demak V yang berpusat di Jipang. Berkaitan dengan serangan Hadiwijaya, masyarakat Cepu yakin yang memberontak adalah Hadiwijaya. Alasannya, pemberontak adalah pihak yang menyerang pusat kerajaan. Hal ini menjadi alasan mengapa Kushariyadi mendirikan Yayasan Keraton Jipang yang dipimpin seorang raja, bukan Kadipaten Jipang yang dipimpin seorang adipati.

Masyarakat Cepu memiliki memori kolektif atas Arya Penangsang dan Kadipaten Jipang sebagaimana tampak dalam beberapa situs dan peninggalan sejarah. Masyarakat Cepu mengerti bahwa bekas pusat Kadipaten Jipang terletak di Desa Jipang, sekitar $7 \mathrm{~km}$ arah barat laut Kota Cepu. Makam Gedong Ageng Jipang dan pendopo yang ada di Desa Jipang dianggap sebagai bekas bangunan utama Kadipaten Jipang pada masa lalu. Dua tempat ini sekarang dijaga oleh seorang juru kunci. Juru kunci bertugas menerima tamu peziarah atau tamu yang mencari informasi sejarah Arya Penangsang dan Kadipaten Jipang. Juru kunci dianggap sebagai sesepuh dan tokoh budaya (Sukarjan (62), juru kunci Makam Gedong Ageng Jipang dalam wawancara di rumahnya di Desa Jipang, Cepu tanggal 11 Januari 2018).

Sebagai bekas pusat Kadipaten, Desa Jipang bagian selatan berbatasan dengan Sungai Bengawan Solo, bagian barat berbatasan dengan Desa Ngloram dan Desa Kapuan (dahulu dipisahkan oleh Bengawan Sore yang sekarang berubah menjadi area persawahan), bagian utara berbatasan dengan Desa Kapuan dan Getas (dipisahkan oleh Kali Kecing), dan bagian timur berbatasan dengan Desa Getas (dipisahkan Kali Kecing) dan Sungai Bengawan Solo yang menjorok ke daratan bertemu hilir Kali Kecing.

Hal ini mengingatkan kita, orang Jawa memilih ibukota kerajaan dan candi pada masa HinduBudha di antara pertemuan dua sungai. Ini senada dengan penjelasan Kushariyadi yang mengatakan Jipang bukanlah wilayah yang baru berdiri bersamaan dengan menguatnya Kesultanan Demak. Menurutnya, Jipang adalah bekas kerajaan tua yang sudah ada sejak zaman Majapahit dan diperintah oleh keturunan keluarga Majapahit.

Beberapa warga bisa menceritakan di mana dulu berdiri bangunan-bangunan pemerintahan era Kadipaten Jipang. Penamaan bagian persawahan mencerminkan hal tersebut. Sawah Cinde 
menunjukkan taman kadipaten. Sawah Padon menunjukkan pengadilan. Sawah Segaran menunjukkan kolam kadipaten, disebut juga Sawah Ngawan Anyar. Sawah Babalayar menunjukkan alun-alun untuk upacara dan pementasan. Dan, Sawah Ngawan Sore yang menunjukkan persawahan di bekas sodetan Sungai Bengawan Solo yang dibelokkan ke sungai Kali Kecing.

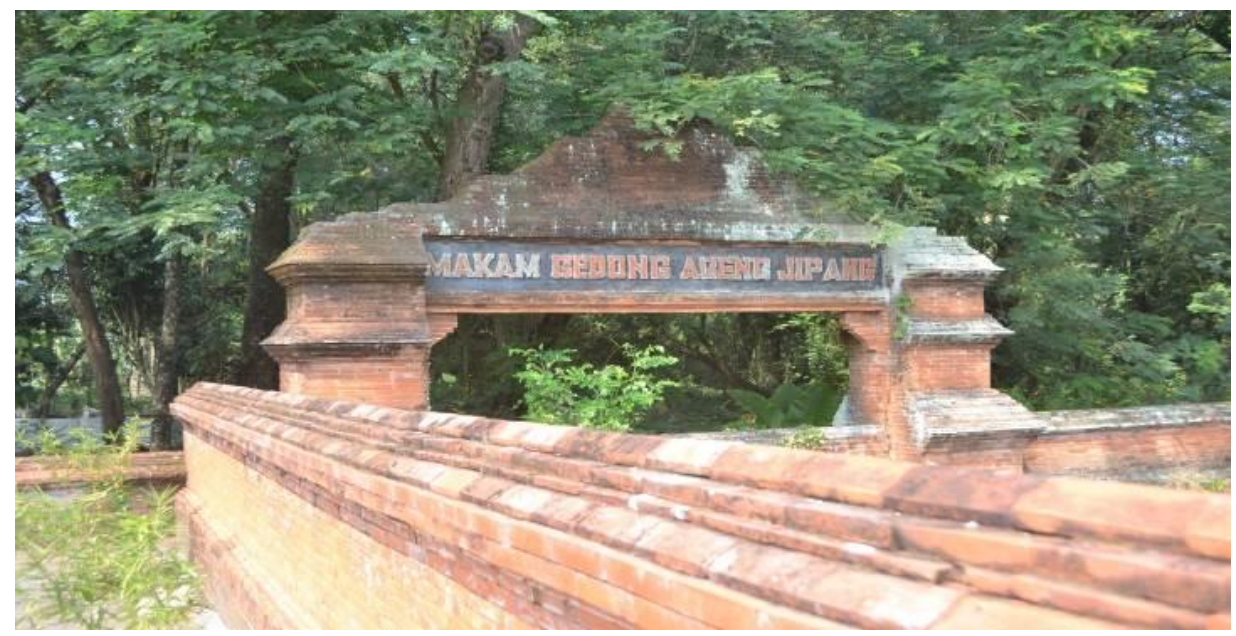

Gambar 2 Makam Gedong Ageng di Desa Jipang Sumber: Sukarjo Waluyo

Area Makam keluarga Gedong Ageng dan bekas pendopo kadipaten sekarang ini banyak dikunjungi peziarah dan orang yang ingin mengetahui kisah Arya Penangsang dan Kadipaten Jipang. Kedua situs tersebut dibangun oleh Pemerintah Kabupaten Blora sebagai cagar budaya. Gambar 3 Makam Gedong Ageng di Desa Jipang adalah petilasan Arya Penangsang dahulu sering berziarah dan mengenang leluhurnya. Pendopo sekarang diperkirakan tempat dimana pendopo kadipaten pada masa lalu berdiri. Area persawahan luas di seberang makam keluarga Gedong Ageng dan pendopo adalah alun-alun, taman kota, masjid, kolam segaran, dan bangunan-bangunan pemerintahan.

Bengawan Sore adalah sodetan Sungai Bengawan Solo yang dialirkan menuju Sungai kali Kecing dan yang sangat dikenal oleh masyarakat Jawa. Dalam ceita tutur Jawa, Bengawan Sore adalah tempat terjadinya legenda perang antara Arya Penangsang dengan Danang Sutawijaya, anak angkat Hadiwijaya yang kelak menjadi Raja Mataram I bergelar Panembahan Senapati ing Alaga Sayidin Panatagama Khalifatullah Tanah Jawa. Panembahan Senapati inilah yang selanjutnya menurunkan raja-raja di Keraton Surakarta dan Keraton Yogyakarta. Dalam perang tersebut, Arya Penangsang dikisahkan terbunuh dengan dramatis. Ususnya terburai karena lambungnya tertusuk tombak Kyai Plered milik Dananng Sutawijaya. Arya Penangsang menaruh ususnya pada gagang keris Setan Kober miliknya pada bagian pinggulnya. Dengan gagah berani, Arya Penangsang melanjutkan peperangan melawan Danang Sutawijaya. Arya Penangsang berhasil meringkus lawannya, tetapi saat ia menarik keris, senjata tersebut justru memotong ususnya sendiri. Arya Penangsang pun tewas oleh senjatanya sendiri (Graaf, 1985; Olthof, 1987). 


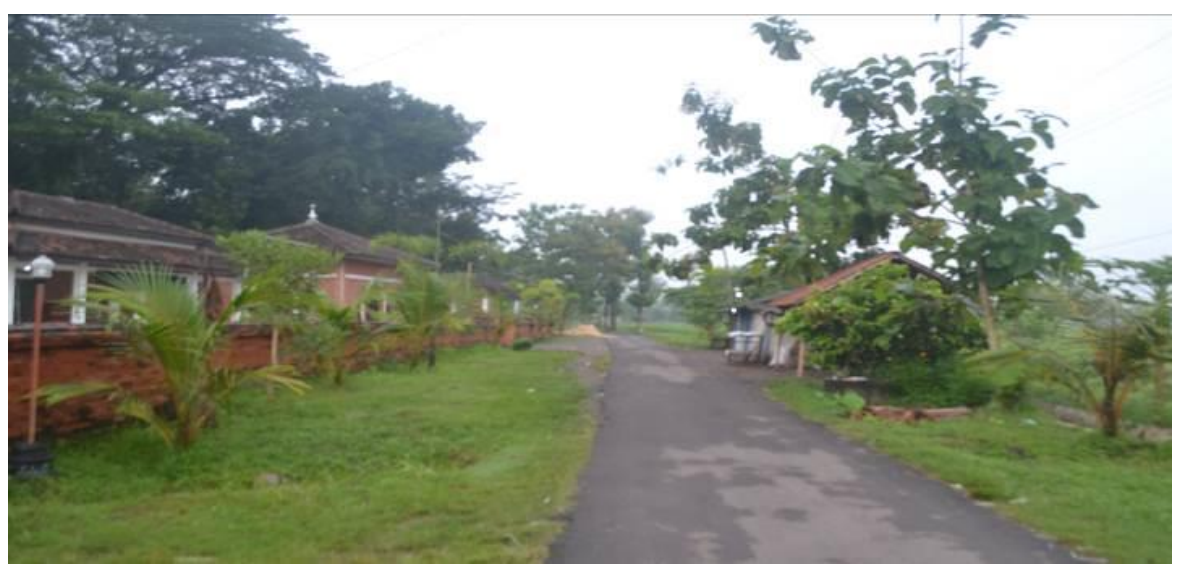

Gambar 4 Bekas Pendopo Kadipaten Jipang

Sumber: Sukarjo Waluyo

Desa Jipang yang pernah menjadi pusat kadipaten berada di pertemuan dua sungai (Sungai Bengawan Solo dan Sungai Kali Kecing). Gambar 5 Bekas Pendopo Kadipaten Jipang (dipercaya sebagai tempat berdirinya bangunan kadipaten pada masa lalu. Pada masa lalu, Kadipaten Jipang menyodet Bengawan Solo yang dialirkan ke Sungai Kali Kecing. Alhasil, Jipang tampak sebagai wilayah terapung dan sulit dimasuki orang. Sodetan berfungsi sebagai benteng sungai dan gerbang barat yang dibuka pada waktu sore dan ditutup saat pagi hari. Bengawan Sore juga difungsikan untuk irigasi bagi area persawahan yang luas di sekitar Jipang.

Dalam kepercayaan masyarakat Jipang, Bengawan Sore ditanami rajah palacakra oleh Sunan Kudus yang berfungsi untuk menolak bahaya. Sekarang, Bengawan Sore sudah berubah menjadi area persawahan. Menurut Sukarjan dan penuturan warga, area persawahan yang agak rendah di bagian barat desa tersebut adalah bekas Bengawan Sore, dinamai Sawah Ngawan Sore.

Desa Jipang pada masa lalu memiliki ring road pada bagian luar desa yang membatasinya dengan Sungai Bengawan Solo, Sungai Kali Kecing, dan Bengawan Sore. Saat ini Pemerintah Desa Jipang membangun kembali dengan jalan paving. Ini adalah bagian dari visi pemerintah Desa Jipang membangun desa wisata sejarah. Pengunjung menggunakannya untuk berjalan-jalan, bersepeda, atau menikmati Sungai Bengawan Solo. Sukarjan menuturkan keyakinan warga jika membangun rumah harus menghadap ke jalan tersebut. Rumah-rumah menghadap ke Sungai Bengawan Solo dibatasi jalan kecil, tetapi Desa Jipang aman dari banjir Sungai Bengawan Solo. Warga yakin leluhur mereka sudah membentengi desa dari ancaman banjir Sungai Bengawan Solo.

Saat ini ada beragam penyebutan Jipang sebagai bekas Kadipaten besar di Jawa pada masa lalu. Masyarakat Jawa di luar Cepu menyebut Kadipaten Jipang sebagai Jipang, Jipang Panolan, atau Jipang Panolang. Sukarjan menuturkan bahwa yang benar adalah Kadipaten Jipang. Setelah kekalahan Jipang dan Arya Penangsang wafat, Sultan Hadiwijaya mengangkat putranya (Pangeran Benawa) sebagai Adipati Jipang. Namun, karena area ibukota Kadipaten Jipang hancur akibat perang, Pangeran Benawa memindahkan pusat kadipaten sekitar $1 \mathrm{~km}$ ke arah barat, yaitu di Desa Panolan. Muncullah penyebutan baru yaitu Jipang Panolan. Sementara itu, Jipang Panolang adalah kesalahan penyebutan oleh orang di luar Cepu (dalam Kethoprak atau tari Soreng). Kini Jipang dan Panolan menjadi dua desa yang berbeda. Desa Jipang adalah bagian Kecamatan Cepu, sedangkan Desa Panolan adalah bagian Kecamatan Kedungtuban. Keduanya bagian administratif dari Kabupaten Blora, Provinsi Jawa Tengah.

Jipang akhirnya adalah kiblat sejarah dan budaya wilayah Cepu dan sekitarnya. Acara berlatar belakang sejarah dan budaya di Kota Cepu sekarang ini mulai dikapitalisasikan oleh aktivis muda, pegiat budaya, komunitas-komunitas, dan Pemerintah Kabupaten Blora. Beberapa di antaranya adalah sebagai berikut. 
Upacara pengangkatan juru kunci.

Juru kunci adalah jabatan budaya, yaitu penjaga tempat keramat, makam kerajaan, atau makam orang terhormat. Juru kunci di Pulau Jawa biasanya diberi nama dan status. Profesi juru kunci bersifat turun-temurun dan merupakan orang yang tahu sejarah dan filosofi tempat yang dijaganya. Juru kunci tidak mendapatkan gaji, tetapi memiliki kedudukan penting dan terhormat di kalangan masyarakat adat. Sukarjan adalah juru kunci Makam Gedong Ageng Jipang yang sudah menjalani profesinya sekitar dua puluh tahun. Dalam suatu kesempatan ia mendapatkan bisikan gaib mendapatkan gelar "Haryo" yang kemudian disampaikannya kepada Bupati Blora, Djoko Nugroho. Pada bulan Januari 2014, Bupati Blora mewisuda Sukarjan dalam upacara adat di pendopo Makam Gedong Ageng yang disaksikan warga, tokoh masyarakat, pejabat pemerintah, dan budayawan Cepu.

Komunitas budaya dan warung kopi kothok.

Eksistensi sejarah, budaya, dan identitas lokal Cepu bukanlah sesuatu yang tiba-tiba. Ada kebiasaan warga Cepu bersosialisasi di warung kopi dalam suasana santai. Warung kopi di Kota Cepu tersebar di berbagai tempat dengan sederhana, ada tempat duduk dan meja untuk sekitar dua puluh orang. Warung kopi khas Cepu yang disebut kopi kothok konon sudah ada sejak zaman Kadipaten Jipang dan menjadi sarana bersosialisasi para warga. Dari diskusi-diskusi kecil di warung kopinya terbentuk beberapa komunitas budaya, seperti Paguyuban Malem Jemuah Pahing (PMJP), Jamaah Ngopi, dan Paguyuban Ngothok Kawruh (Hery Walet (58), seorang pegiat budaya Cepu dan seorang pemilik warung kopi dalam wawancara di warung kopinya, tanggal 10 Januari 2018).

Gelar budaya dan seni Jipang.

Adat dan budaya Jipang semakin mendapat pengakuan melalui Gelar Budaya Jipang yang dihadiri oleh 40 utusan raja dan sultan se-Indonesia di Desa Jipang pada bulan Desember 2012. Hal ini membuat Kushariyadi, Ketua Yayasan Keraton Jipang, mengumpulkan saudara-saudaranya dan merunut silsilah keluarga Kadipaten Jipang yang tersebar hingga ke luar Jawa. Juga mengajak tokohtokoh Cepu yang peduli dengan upaya revitalisasi kejayaan Kadipaten Jipang pada masa lalu.

Seni khas Kadipaten Jipang mulai dikembangkan lagi oleh seniman Cepu.

J.F.X Hoery menuturkan bahwa masyarakat Cepu di masa lalu akrab dengan wayang krucil dan wayang thengul. Tokoh dalam wayang krucil kepala dan badannya terbuat dari kayu, sedangkan tangannya terbuat dari kulit. Wayang ini untuk mementaskan cerita Panji pada zaman Kediri. Tokoh dalam wayang thengul terbuat dari kayu yang menyerupai tubuh manusia secara utuh (mirip wayang golek di Jawa Barat). Wayang ini untuk mementaskan cerita Menak (Timur Tengah) atau Jawa masa Demak dan para wali (penyebar agama Islam di Jawa). Kedua jenis wayang ini bisa dipentaskan dengan praktis dibandingkan wayang purwa yang terikat pakem dan gamelan. Wayang krucil dan wayang thengul hanya menggunakan perangkat gamelan sederhana, seperti kendang, bonang, saron, dan kempul. Kisahnya juga lebih fleksibel, yaitu berupa nasihat atau kritik sosial.

\section{Cepu: Bumi Arya Jipang}

Memori kolektif masyarakat Cepu atas Arya Penangsang dan Kadipaten Jipang tampak dalam bangunan-bangunan di ruang-ruang publik. Hal ini menunjukkan bahwa wilayah Cepu adalah identik dengan Arya Penangsang, di Cepu lebih dikenal dengan Arya Jipang. Namanya diabadikan menjadi nama jalan yang memanjang dari Stasiun Kereta Api Cepu menuju ke Desa Jipang yang berjarak sekitar $7 \mathrm{~km}$. Tampak penulisan berbeda-beda untuk maksud sama, seperti Aryo Jipang, Ario Jipang, Haryo Jipang, Arya Jipang, dan Arjip yang bertebaran di papan nama kantor pemerintah, sekolah, toko, masjid dan lain-lain. Hal ini menunjukkan kebanggaan masyarakat Cepu atas pahlawan lokalnya. 


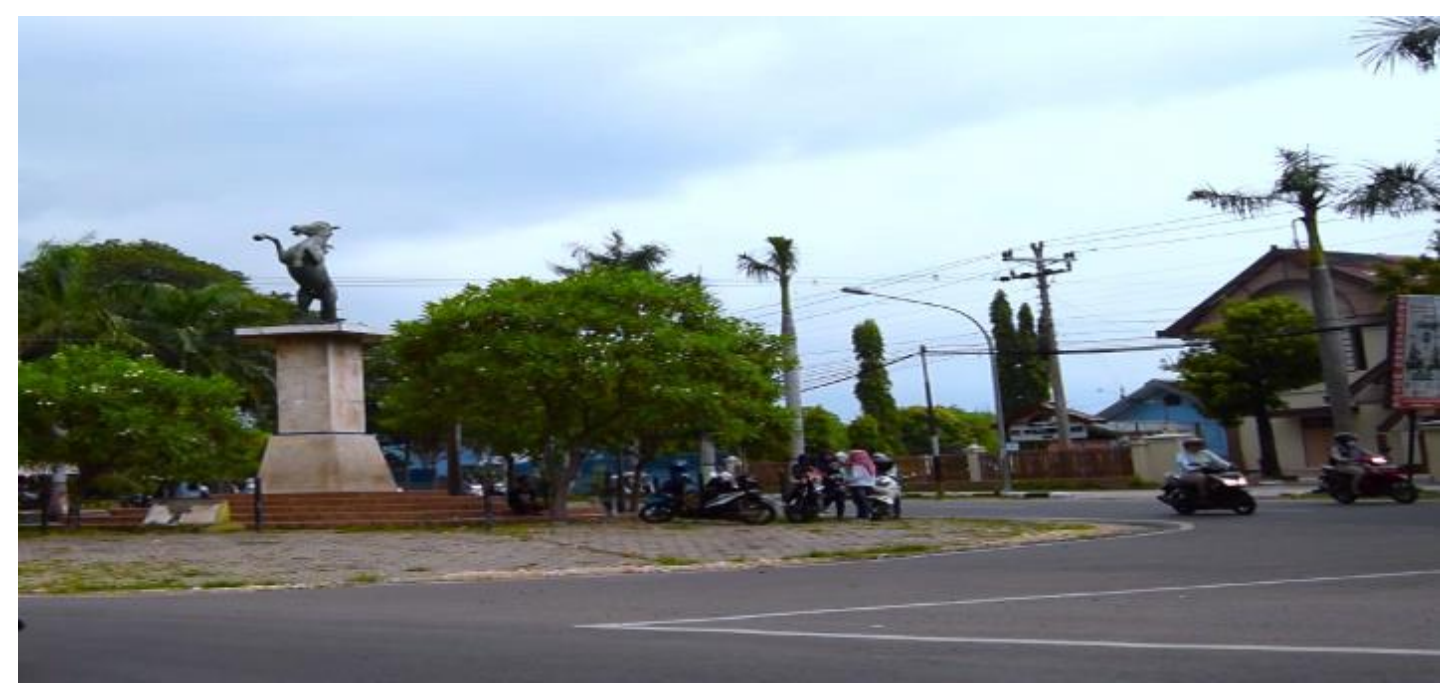

Gambar 6 Kuda Gagak Rimang menjadi ikon Kota Cepu

Sumber: Sukarjo Waluyo

Gambar 7 Kuda Gagak Rimang menjadi ikon Kota Cepu adalah hal yang menarik dan berdiri gagah di pusat Kota Cepu. Penuturan J.F.X. Hoery, pada masa kolonialisme Belanda Cepu terkenal dengan pertambangan minyak bumi. Di pusat kota, Pemerintah Kolonial Belanda membangun patung Ratu Willhelmina. Hal ini menunjukkan Cepu sebagai kota penting dan mendapat perhatian dari Pemerintah Kolonial Belanda. Ketika Indonesia merdeka tahun 1945, euforia masyarakat ditunjukkan dengan merobohkan patung Ratu Willhelmina yang dianggapnya sebagai simbol kelonialisme.

Tahun 1984 Yayasan Ronggolawe dan Pemerintah Kabupaten Blora membangun patung kuda Ronggolawe di bekas patung Ratu Willhelmina. Yayasan Ronggolawe adalah yayasan yang menaungi mantan pasukan TNI dari Divisi Ronggolawe pimpinan Djati Kusumo yang terkenal dalam merebut kemerdekaan dan menumpas pemberontakan PKI Madiun 1948. Namun, masyarakat Cepu menyebutnya sebagai Patung Kuda Gagak Rimang karena identik dengan persepsi masyarakat Cepu tentang kuda Gagak Rimang, yaitu kuda jantan hitam dan mengangkat kedua kaki depannya. Konvensi ini menunjukkan memori kolektif yang ingin dekat dengan sejarah, budaya, dan identitas lokalnya. Gagak Rimang adalah kuda kesayangan Arya Penangsang yang turut gugur dalam perang.

Sementara itu, taman-taman kota di Kota Cepu tampak mengakomodasi sejarah, budaya, dan identitas lokalnya. Misalnya Taman Aryo Jipang di pintu masuk kota. Sementara itu, di tengah kota berdiri Taman Patih Mentaun. Patih Mentaun adalah patih legendaris Jipang yang terbunuh dalam perang. Patih Mentaun adalah tokoh yang mengabdikan hidupnya kepada Kadipaten Jipang. Ia dikenang sebagai orang bijaksana, tegas, pengayom, ahli pemerintahan, dan ahli strategi perang.

\section{Upaya Revitalisasi Sosok Arya Penangsang dan Kejayaan Keraton Jipang oleh Yayasan Keraton Jipang}

Kushariyadi sejak tahun 2000-an membangun wacana revitalisasi Keraton Jipang. Dalam catatan "Jejak dan Langkah dalam Upaya Melestarikan Adat dan Budaya Kraton Jipang" (2017), ide ini dimulai ketika pembangunan Masjid Nurul Iman Desa Demaan, Kecamatan Padangan, Kabupaten Bojonegoro. (sekitar $1 \mathrm{~km}$ sebelah timur Kota Cepu) pada tanggal bulan Mei 2004. Selanjutnya, ia menemukan manuskrip Sejarah Jipang pada tanggal 27 September 2005 di lokasi masjid. Sejak itulah Kushariyadi berusaha membangun komunikasi dan merunut trah (garis keturunan) Keraton Jipang. Ia mendirikan "Komunitas Wargo Penget" pada tahun 2005-2014 yang akhirnya menjadi embrio pendirian Yayasan Keraton Jipang pada tahun 2016.

Ide pendirian Yayasan Keraton Jipang dimulai dari pertemuan dengan keturunan Jipang dari Ogan Komiring Ulu, Sumatera Selatan yaitu Barik Barliyan. Barik Barliyan adalah keturunan Arya Mataram (adik Arya Penangsang) yang datang pada sebuah kesempatan di Cepu tanggal 13 Juli 2014. 
Pertemuan tanggal 14 Juli 2014 mengundang budayawan dan mendiskusikan upaya mengangkat sejarah dan budaya Kraton Jipang. Tanggal 15 Juli 2014, kesepakatan mengangkat Raja Jipang melalui Musyawarah Dewan Adat yang memilih Barik Barliyan. Agenda berikutnya adalah melakukan komunikasi dengan Forum Silaturahmi Keraton Nusantara (FSKN). Kelengkapan pendaftaran sebagai anggota FSKN juga disiapkan, yaitu nama raja dan kelengkapannya: silsilah, peninggalan keraton berupa keris, dan manuskrip.

Pendirian Yayasan Keraton Jipang terlaksana pada tahun 2016. Kantor yayasan dibangun di Jalan Aryo Jipang, Desa Kentong (2017), mendirikan media Koran Jipang Pos (2017), dan mengadakan gelar budaya Kraton Jipang pada tanggal 10 Agustus 2017 di Taman Mini Indonesia Indah (TMII), Jakarta. Keraton Jipang juga diundang Presiden Joko Widodo pada Upacara HUT RI ke-70 pada tanggal 17 Agustus 2015 di Istana Negara, Jakarta. Beberapa kegiatan diadakan, di antaranya menghadiri undangan pada Forum Raja Malaka tahun 2014, Silaturahim Nasional Raja Sultan di Bima tahun 2014, Silaturahim Nasional Raja Sultan di Bali tahun 2015, dan mengadakan Gelar Budaya Kraton Jipang pada tahun 2016 di Cepu tanggal 15-17 November 2016.

Oleh sebagian pihak, penulisan sejarah Keraton Jipang seringkali dicurigai ditulis dengan kepentingan untuk "mengubur" kejayaan Jipang masa lalu. Sejarah resmi tidak mengakomodasi suara Jipang, terutama setelah kekalahan Jipang dalam perang. Meski kalah, keluarga Kadipaten Jipang yang melarikan diri ke Surabaya dan Palembang menganggap serangan pihak Pajang adalah pemberontakan (KPRA Barik Barliyan, S.H. (46), Raja Keraton Jipang dalam wawancara saat acara Pemilihan Duta Keraton Jipang di area Blok T Kota Blora, tanggal 11 Maret 2018). Barliyan mengemukakan bahwa perjalanan sejarah Kesultanan Demak bisa dibagi menjadi tiga bagian, yaitu: Tahap pertama, Kesultanan Demak Bintoro yang ditandai dengan berdirinya Kesultanan Demak di daerah Glagah Wangi oleh Raden Patah (1478-1518 M). Setelah Raden Patah (Sultan Demak I) meninggal digantikan oleh Pati Unus (Sultan Demak II yang memerintah tahun 1518-1521 M). Pati Unus yang meninggal dan tidak memiliki anak digantikan oleh Pangeran Trenggana yang diwarnai pembunuhan atas kakaknya (Pangeran Sekar) oleh Pangeran Prawata (anak Sultan Trenggana). Sultan Trenggana (Sultan Demak III yang memerintah 1521-1546 M) diakui membawa kemajuan meski diwarnai dendam anak Pangeran Sekar, yaitu Arya Penangsang.

Tahap kedua adalah Kesultanan Demak Prawata. Setelah Sultan Trenggana wafat, tahta Demak Bintoro jatuh ke Pangeran Prawata (Sultan Demak IV). Masa itu, ibukota dipindah ke Prawata (Sukolilo, Kabupaten Pati) yang disebut Demak Prawata. Arya Penangsang melihat Kesultanan Demak lemah sehingga Arya Penangsang melakukan balas dendam dan meminta haknya kembali atas tahta yang seharusnya jatuh ke tangan ayahnya. Dan tahap ketiga adalah Kesultanan Demak Jipang. Arya Penangsang mengangkat diri sebagai Sultan Demak V, muncul istilah Demak Jipang. Selain Arya Penangsang, masyarakat Cepu sangat menghormati Sunan Kudus dan Patih Mataun. Sunan Kudus berada di belakang sejarah dan perjuangan Keraton Jipang. Sementara itu, Patih Mataun adalah patih Jipang yang dari muda hingga wafat berjuang untuk Keraton Jipang. Kedua tokoh tersebut menjadi saksi langsung kedua Adipati Jipang, Pangeran Sekar dan Arya Penangsang, tokoh yang berhak atas tahta Kesultanan Demak, tetapi tahta jatuh ke orang lain.

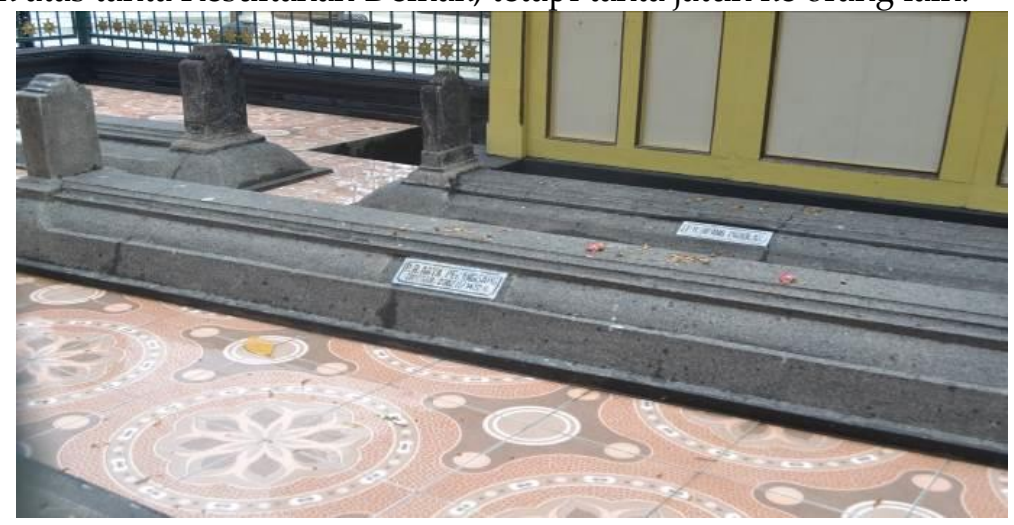

Gambar 8 Makam Arya Penangsang di Kompleks Makam Keluarga Kesultanan Demak Sumber: Sukarjo Waluyo 
Barliyan melihat apa yang tercatat di Museum Masjid Agung Demak sebagai politisasi sejarah Kesultanan Demak oleh penguasa Jawa di era Pajang dan Mataram. Misalnya, setelah wafatnya Sultan Trenggana pada tahun 1546 M tidak ada pengganti dari keturunan Raden Patah yang menggantikannya. Sementara itu, Sultan Hadiwijaya baru berkuasa di Kesultanan Pajang tahun 1560 M. Dinasti baru muncul di Jawa karena Hadiwijaya bukan keturunan Raden Patah, pendiri Kesultanan Demak. Lebih lanjut, Barliyan mengatakan masa 14 tahun diwarnai perebutan tahta oleh keturunan Raden Patah (anak Sultan Trenggana dan anak Pangeran Sekar). Berdirinya Kesultanan Demak Jipang adalah sah karena sepeninggal Pati Unus, Pangeran Sekar yang berhak menjadi Sultan Demak, bukan Sultan Trenggana. Dalam Pandangannya, Hadiwijaya adalah seorang pemberontak dan tidak memiliki hak atas tahta Demak. Gambar 9 Makam Arya Penangsang di Kompleks Makam Keluarga Kesultanan Demak yang bisa ditemukan di Kompleks Makam Keluarga Kesultanan Masjid Agung Demak membuktikan bahwa ia keturunan langsung Raden Patah. Makam Arya Penangsang ada di dua tempat, yaitu di Kompleks Makam Keluarga Kesultanan Masjid Agung Demak dan Kompleks Makam Sunan Kalijaga, Kadilangu, Demak. Keluarga dan keturunan Kadipaten Jipang meyakini bahwa makam sebenarnya ada di Kompleks Makam Sunan Kalijaga, Kadilangu, Demak.

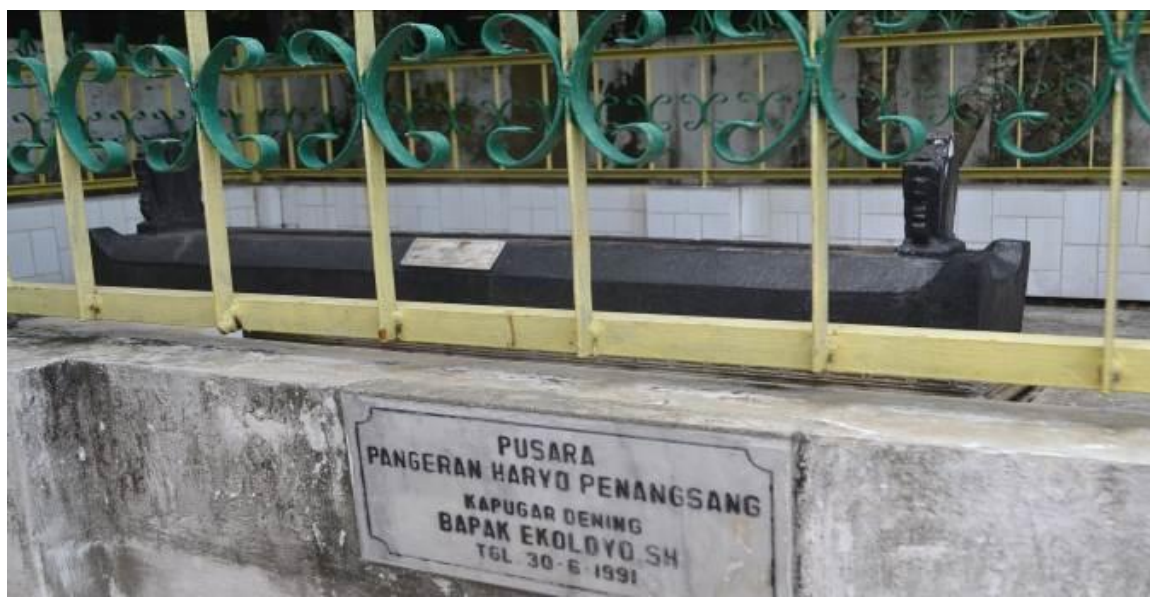

Gambar 10 Makam Arya Penangsang di Kompleks Makam Sunan Kalijaga, Kadilangu, Demak Sumber: Sukarjo Waluyo

Gambar 11 Makam Arya Penangsang di Kompleks Makam Sunan Kalijaga, Kadilangu, Demak juga diakui keberadaannya oleh Barliyan. Ia mengungkapkan, dimakamkannya Arya Penangsang di Kompleks Makam Sunan Kalijaga, Kadilangu, Demak yang dipercaya sebagai makam yang sebenarnya ada beberapa alasan, antara lain: 1) Arya Penangsang adalah Keluarga Kesultanan Demak. Arya Penangsang adalah keluarga Kesultanan Demak. Kematian yang tragis dalam pertempuran tidak serta-merta Arya Penangsang akan dijatuhkan oleh pihak Kesultanan Demak. Setelah meninggal ia harus dihormati sebagaimana layaknya seorang pangeran; 2) Pertimbangan politik oleh pihak pemenang perang Pajang - Jipang. Arya Penangsang adalah seorang pemimpin yang kharismatik dan banyak pengikutnya di Jipang dan sekitarnya. Upaya menjauhkan makam dari daerah yang dipimpinnya adalah perhitungan politik, meredam gejolak dan balas dendam; dan 3) Sunan Kalijaga mengusahakan rekonsiliasi. Sunan Kalijaga adalah seorang pemimpin spiritual. Ia harus rekonsiliatif dan berdiri di atas banyak kepentingan. Arya Penangsang dimakamkan wilayahnya adalah upaya menjadi "bapak yang bijaksana". Bapak yang menjaga keharmonisan keluarga Kesultanan Demak yang baru dilanda konflik dan membuat Arya Penangsang terbunuh. Bahkan upaya pemindahan Kesultanan dari Demak ke Pajang tidak lepas dari pengaruh Sunan Kalijaga untuk meredam konflik kepentingan sesama keluarga Kesultanan Demak. Hadiwijaya dipilih karena dianggap netral dan diharapkan bisa diterima oleh berbagai kalangan.

Sunan Kudus yang sangat dihormati di Cepu (bekas kekuasaan Kadipaten Jipang di masa lalu) berbanding lurus dengan penghormatan Adipati Arya Penangsang di Kudus. Pintu masuk ke area Kompleks Makam Sunan Kudus di sebelah Masjid Menara Kudus mengabadikan nama Adipati 
Jipang sebagai Gapura Arya Penangsang. Gapura tersebut dahulu menjadi tempat Arya Penangsang belajar ilmu agama dan pemerintahan sebagai murid yang disayangi oleh Sunan Kudus.

Arsitektur Masjid Menara Kudus yang didominasi batu bata merah mengingatkan kita pada upaya revitalisasi Keraton Jipang yang banyak menampilkan hal sama. Menurut Ketua Yayasan Keraton Jipang, Kushariyadi, upaya revitalisasi berkaitan dengan arsitektur Kadipaten Jipang memiliki dua pesan: 1) Arsitektur Majapahitan pada upaya revitalisasi Keraton Jipang. Sebelum Kesultanan Demak berdiri, Jipang adalah kerajaan kecil yang mengakui kekuasaan Majapahit dan dipimpin oleh keturunan Majapahit. Ada upaya budayawan dan seniman untuk mencari kekhasan arsitektur Jipang yang condong ke Majapahit. Hal ini untuk membedakan dengan gaya arsitektur Demak yang dipersepsi sebagai rival secara politik dan budaya dan 2) Arsitektur Masjid Menara Kudus pada upaya revitalisasi Keraton Jipang. Arsitektur Majapahitan yang diakomodasi dalam pembangunan Masjid Menara Kudus menjadi inspirasi revitalisasi bangunan khas Jipang di Cepu. Sikap politik Sunan Kudus pada masa lalu memberikan dukungan kepada Pangeran Sekar dan Arya Penangsang saat konflik dengan keluarga Kesultanan Demak. Hal ini membuat budayawan dan seniman merasa lebih menerima jika revitalisasi arsitektur lebih mengakomodasi arsitektur Masjid Menara Kudus.

\section{Kesimpulan}

Cepu adalah kota tua di Kabupaten Blora, Provinsi Jawa Tengah. Cepu memiliki kebanggaan atas pahlawan lokalnya yang bernama Arya Penangsang dan wilayah masa lalunya yaitu Kadipaten Jipang. Meskipun oleh masyarakat Jawa di Surakarta dan Yogjakarta Arya Penangsang dianggap sebagai pemberontak yang jahat, kasar, dan haus kekuasaan, tetapi masyarakat Cepu justru berpandangan sebagai pemimpin tegas, membela kebenaran, berani menuntut hak.

Akhir-akhir ini, ada upaya masyarakat Cepu untuk menghidupkan kembali pahlawan lokal Arya Penangsang dan kebesaran masa lalu Kadipaten Jipang. Masyarakat Cepu memiliki memori kolektif sebagaimana tampak dalam beberapa situs dan peninggalan, seperti bekas area kadipaten Jipang, makam keluarga Gedong Ageng dan pendopo kadipaten, Bengawan Sore, jalan kuno mengelilingi area Jipang, dan Jipang sebagai kiblat sejarah dan budaya Cepu

Memori kolektif masyarakat Cepu atas Arya Penangsang dan Kadipaten Jipang juga tampak dalam bangunan-bangunan di ruang-ruang publik, seperti nama jalan, patung kuda Gagak Rimang di pusat kota, dan nama-nama taman kota. Upaya revitalisasi sosok Arya Penangsang dan kejayaan Keraton Jipang juga diinisiasi oleh Yayasan Keraton Jipang. Yayasan yang berdiri tahun 2016 tersebut rajin mengadakan even budaya dan membangun jaringan. Yayasan ini juga berusaha membangun wacana atas penulisan sejarah Jipang yang tidak menampung suara mereka. Misalnya, Arya Penangsang pernah mengangkat diri sebagai Sultan Demak V dan memunculkan istilah Demak Jipang.

\section{Referensi}

Aden, F. (2013). The Hidden Hystory. Yogyakarta: Pustaka Radhiya.

Graaf, H. J. de. (1985). Awal Kebangkitan Mataram (Masa Pemerintahan Senopati). Jakarta: Pustaka Grafitipers.

Graaf, H. J. de, \& Pigeaud, T. G. (1985). Kerajaan-kerajaan Islam di Jawa. Jakarta: Pustaka Grafitipers.

Green, A. (2004). Individual Remembering and "Collective Memory": Theoretical Presuppositions and Contemporary Debates. Oral History, 32(2), 35-44.

Hobswamb, E., \& Ranger, T. (Ed.). (1983). The Invention of Tradition. Cambridge: Cambridge University Press.

Klapp, B. O. E. (1949). The Folk Hero. The Journal of American Folklore, 62(243), 17-25. https://doi.org/10.2307/536852

Larson, J. A., \& Lizardo, O. (2007). Generations, identities, and the collective memory of Che Guevara. Sociological Forum, 22(4), 425-451. https://doi.org/10.1111/j.1573-7861.2007.00045.x

Leve, L. (2011). Identity. Current Anthropology, 52(4), 513-535. https://doi.org/10.1086/660999

Luxford, J. M. (20093). An English Chronicle Entry on Robin Hood. Journal of Medical Hystory, 3:51, 70-76.

Nanney, N. K. (1988). Evolution of a Hero: The Hang Tuah/Hang Jebat Tale in Malay Drama. Asian Theatre Journal, 5(2), 164-174. 
Olthof, W. L. (1987). Babad Tanah Djawi. Dordrecht-Holland: Foris Publications.

Spradley, J. P. (2007). Metode Etnografi. Yogyakarta: Tiara Wacana.

Suart Hall, David Held, A. M. (1992). The Questions of Cultural Identity. Cambridge: Polity Press in Association with The Open University.

Waluyo, S. (2019). Hegemoni Jawa Mataraman dalam Tari Soreng sebagai Ikon Budaya Kabupaten Magelang. Endogami: Jurnal Ilmiah Kajian Antropologi, 3(1), 85. https://doi.org/10.14710/endogami.3.1.85-99

Waluyo, S. (2020). Arya Penangsang: Potret Sejarah Pertarungan Jawa Pesisir vs Jawa Pedalaman. Yogyakarta: Ombak. Waluyo, S., \& Noor Ary Setyadi, R. (2020). The Existence of Jipang Village as a Collective Builder Cepu Community in Blora Regency. E3S Web of Conferences, 202, 07012. https://doi.org/10.1051/e3sconf/202020207012

Weiser, F. (2013). Writing "Che" Writing: Apocryphal Diaries and the Deconstruction of Guevara's Myth. Hispania, 96(4), 700-711. https://doi.org/10.1353/hpn.2013.0126

Wulf Kansteiner. (2002). Finding Meaning in Memory: A Methodological Critique of Collective MemoryStudies. History and Theory, 41(2), 179-197.

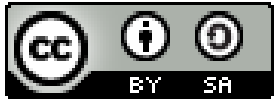

(C) 2021 by the authors. Submitted for possible open access publication under the terms and conditions of the Creative Commons Attribution (CC BY SA) license (https://creativecommons.org/licenses/by-sa/3.0/). 